\title{
技術報告
}

\section{6. 仮想評価法による人々の電源選好意識の把握}

\author{
高橋 玲子1,*，中込 良廣1 \\ Contingent Valuation Method Applied to \\ Survey on Personal Preferences on Choice of Electric Power Source
}

Reiko TAKAHASHI and Yoshihiro NAKAGOME

\begin{abstract}
A Survey was conducted on personal preferences regarding their choice of electric power source to verify the applicability of Contingent Valuation Method (CVM) to such analysis. The survey was carried out on local and urban inhabitants in two steps, first by mail and thereafter by direct interview. A choice of four typical forms of power source was presented: nuclear, coal, hydro and green power; and the question was asked whether the respondent would be willing to pay additional charge for specifying their preferable power source. The mail survey indicated more than half of the respondents hold some willingness to pay either for disuse of nuclear power or expansion of green power. The interview survey revealed various complex motives lying behind their answers. Consequently, it was found that their preference is significantly correlated to their personal image or knowledge of power sources, their thinking or attitude toward energy conservation, their sense of consumption and their private view of life. It is concluded that CVM is pertinently applicable to quantitative analysis of individual opinions, particularly in terms of their motivation to participate in national energy issues. A number of modifications, however, should be required to be brought to the survey design in order to ensure smooth application in practice.
\end{abstract}

KEYWORDS: contingent valuation method, mail survey, interview survey, willingness to pay, participation in national energy policy, attitude toward energy conservation, image on electric power sources, knowledge on energy issues, private view of life

\section{I. 緒言}

近年，太陽光や風力などいわゆる新エネルギーには，供 給面での高コストや不安定性, エネルギー低密度に伴う回 収の非効率性など，電源として実用化するにあたり多くの 克服すべき点が残されているものの, 将来に望むしい電源 として人々の期待が寄せられている。一方，すでに電力供 給の主流である原子力は，エネルギーセキュリティや地球 温暖化抑制の観点から，国策上は基幹とすべき電源にされ ているにもかかわらす，核関連施設や放射性廃棄物に対す る人々の不安感が依然として強く，その利用には十分な国 民的賛同が得られていない1)。このように，個々の電源に 対して必ずしも基本的な特性や位置付けを的確に理解して いるとは考えられないものの，人々はそれぞれの電源に対 して何らかの選好意識を抱いていることは確かである。 このような状況のもとで, 今後は電力自由化拡大の論議 が引き続き進展するに伴って，原子力利用に対する国民の 合意形成が一段と膠着化していくことが予測される。こう した事態打破のひとつの方策として，本報ではわが国の電 源選択の意思決定プロセスに人々が直接関わるというアプ ローチを想定してみる。そのための系口として，まず人々

1 京都大学大学院エネルギー科学研究科 (Graduate School of Energy Sci., Kyoto Univ.)

（2003年 6月25日 受理；2003年 11月11日 査読通過）

*著者連絡先 : Tel. 0724-51-2358, Fax. 0724-51-2608
が問題への関与をどの程度認識しているかを把握するこ と，例えば，仮に電源選択という行動に踏み込むことにな った場合に，どのような意見を表明するかを定量化するこ とが望まれる。しかし，実際のところ，複数の異なった電 源から供給される電力は送電網を通して「一様の電気」と なって消費者に届けられるため, 人々が各自の電源選好意 識を個人としての電源選択行動に結びつけることはそもそ む物理的に無理である。また，たとえ人々に積極的に関与 する意欲があっても，それを直接行動に反映させる具体的 な手段に乏しい。近年では一般家庭に太陽光発電システム が導入されるようになり，グリーン電力基金加入制度も創 設されてはいるが，これらも現在のところ一部の人々の参 加に限られている段階にある。

こうした背景に基づき, 本研究は仮想評価法 (Contingent Valuation Method : CVM)による手法を適用し，人々 の電源選好に対する意識を定量的に捉えることを試みたも のである。CVM とは調査の題材となる対象に関連した仮 定条件を提示し，それが導きうる状況シナリオを具体的に 説明したうえで，その変化を回避するために回答者が個人 として最大限負担しても構わないとする支払い意志額 (Willingness To Pay: WTP) a) 尋ねる手法である2)。本 来, CVM は景観のように何らかの間接的な便益をむたら

\footnotetext{
a) 変化修復のために支払われるべき補償受容額 (Willingness To Accept compensation：WTA）を尋ねる場合むある。
} 
す，いわゆる非利用価値の評価に用いられてきた。本研究 においては，CVMの仮定条件として，まず将来のわが国 の電源選択に人々が直接関与する状況を想定し，この際の 意志の強さをWTP 值により提示することを求めた。む た，人々の電源選択の意見形成に与える影響要因について 分析を試みるために，回答者の持つ意識の背景に関連する 質問項目をさまざまな側面から設定したb)。なお，本来こ のような目的の調査においてはコンジョイント分析による 手法も用いられるが，今回は人々のこうした意識の把握に 対して初めてCVMを試行的に採用することにより， $\mathrm{CVM}$ 適用の有効性を見極めるとともに調查設計の妥当性 について検証を加えることを意図している。

これまでの国内外におけるCVM 適用については，一般 にエネルギー問題以外の分野の調査において数多く見られ るが，電源選択や電気料金に関わる調查に抢いては事例が 少ない。本調査の実施にあたっては，原子力の，いわゆる 外部性評価の観点から関連施設の周辺住民の意識に対して 行われた CVM 調査 ${ }^{3)}$ ，および太陽光や風力など将来の工 ネルギー導入のあり方に対して人々の意見を尋ねた CVM 調査4の 2 つを主に参考にした。また，本調査に先立ち筆 者らは，CVMによる妥当な調查設計条件を概略的に絞込 むためにプレテスト5)を実施しているが，その際に得られ た知見も本調查に反映させた。例えば，今回の調査ではア ンケート調查と訪問調査の 2 つのステップからなる構成 としている。なお，調査対象としては，代表的な電源地域 (立地地域) と需要地域(都市地域)を選定した。前者は原子 力発電所の周辺市町村を, 後者は電力の消費地である大都 市区部としている。これら立地地域と都市地域における人 ふの意識の比較抢よび意識形成の特徵などに関する資料も 得られているが，これらについては別途報告することにし たい。

\section{II. 調 査 方 法}

\section{CVM 適用による設問}

CVM の調查手法を適用することにより，以下の観点に 立った分析が可能となる。

（1）回答者の電源に対する選好意識の度合を，単に個人 の主観の立場から定性的に捉えるのではなく，自ら主 体になって負担するとの観点から定量的に把握するこ とができる。

（2）設問の仮定条件に具体的なシナリオを併記すること によって，質問に対する回答者の理解をより鮮明に し，各自の実情に照らした意見やデータを的確に引き 出すことができる。

その半面，上記のそれぞれの利点に対して，以下のよう な問題点が生じる場合があるc。

（1）もともと量的な価值を持たない対象を価格に換算す ることに回答者が困惑することがある。をた, 調査状 況や時間経過によって回答の再現性が失われる可能性
がある。

（2）仮定条件に例示されたシナリオが不適切な場合に は，回答者に質問の意図が正確に伝わらない恐れがあ る。

これら CVM の不備な点を考慮しつつ, 今回の調査設計 においては以下の点に留意した。

\section{（1）身近な仮定条件の設定}

回答者の価値換算を容易にするために，日常の暮らしに おける電気代を基準にした換算を依頼した。すなわち，電 源構成に自らの意志が反映されるとの仮定のもとに, 従来 の電源を廃止し他の電源でまかなうとした場合に，毎月の 電気代む必然的に上昇するというシナリオを揭げ，その場 合に家庭で月あたり出費できる割増額を尋ねた。参考とし て平均的な家庭の電気料金を示した。また，新エネルギー が主要な電源となるをでに長期間を要することを付記した。

\section{（2）WTP 值の決定要因の把握}

CVM はそもそも個人の意志の強さをWTP 值に換算す ることを前提とした手法であるため, WTP 值は個人の収 入などの経済力 ${ }^{6}$ のほか価值観や考え方などの主観的な要 素にも左右される可能性がある。そこで, 本調査では, WTP 值の決定に影響を及ぼす要因を分析するために，回 答者の持つ用途別の支払い感覚や暮らしにおける豊かさ感 などに関する質問項目を加えた。

\section{(3) アンケート調查と訪問調査の実施}

本調査においては，統計上有意な分量のデータを広く収 集することを目的としたアンケート調査と回答の背景を詳

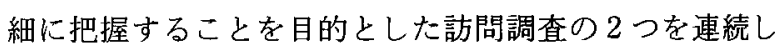
て実施した。両調査の結果を比較することにより，WTP 值の再現性と回答の根拠を確認するとともに, CVM 適用 の可能性の検証ならびに今回の調査設計の妥当性の評価を 行うことを目指した。

\section{(4) 抵抗回答の理由の見極め}

筆者らが本調査に先立って実施したプレテストにおいて は，WTP 值がゼロあるいは無記入であった回答，すなわ ち支払い自体を拒否した回答(以下，抵抗回答と呼ぶ)が約 4 割と大部分を占めていたd)。このため, 抵抗回答の理由

b) 本調査は, CVM を電源選択行動を通して人々の電源選好の意 識を定量化するために適用したものである。仮想条件のもとで の設問であり，実際に原子力の廃止などに必要な費用を分担す る場合の意志を尋ねるものではない。

c) 米国商務省国家海洋大気管理局 (NOAA)は，自然資源の CVM による評価額が損害補償額の決定に影響を与える点に留意し， 1992年にCVM の適用可能性を公開討論により評価した。その 結果に基づき, CVM が信頼性を得るような調查方法の基準を 規定したNOAAガイドラインが作成され，実施にあたっては このガイドラインに従った調査設計が推奖されるようになっ た。ここで挙げた問題点は，このNOAA ガイドラインの指摘 事項を踏をえたうえで，さらに愳念される事項を示したもので ある。

d)一般的な CVMによる調査に扔いて，妥当とされる抵抗回答の 割合は 2 割程度とされている。 
を詳細に探ることが意識の背景分析に役立つものと考え， 今回の調査においては，アンケート調査により多岐にわた る質問事項を設けるとともに，訪問調査を加えることによ って関連の質疑応答を補足することを試みた。

（5）自由回答によるWTP 値の記入

従来に実施された調査においては，原子力の廃止㐫るい は新エネルギーの開発など対象となる電源が単一であった ため， 2 段階 2 肢選択形式e)を採用することができた。こ れに対して, 今回の調査では, 原子力, 石炭火力, 水力お よび新エネルギーの複数の電源について同時に尋ねたので, 2 段階 2 肢選択形式を用いると設問の仕方が煩雑になり， 回答者の負担が増すことになる。そのため, 本調査では具 体的な金額の数値を直接記入する自由回答による方法を採 用した。

\section{2. 調查設計}

今回行ったアンケート調查および訲問調查の設計概要 は，それぞれ以下のとおりである。

\section{(1) アンケート調査}

【実施期間】 2002年 8 月 12 日（月） 23日 (金)

【調査地域】原子力発電所の立地地域(福島県, 新潟県, 福井県の市町村)および大電力消費地として都市地域 (東京 都, 大阪市の区部) とした。調查地域の行政単位を第 1 表 に示す。調査の対象者の抽出は，住民基本台帳に記載され たそれぞれの市町村・区の人口比に従って, 電話帳を用い たランダムサンプリングによった。

【実施方法】アンケート用紙を抽出した世帯の自宅宛に
送付し，対象世帯のうち 1 名加らの回答と返送を依頼し た。回答は原則として無記名方式としたため，回答者が在 住する地域の判別マークを用紙に付した。たたし，訪問調 查への協力を承諾する回答者およびアンケート集計結果の 入手を希望する回答者 (以下，合わせて記名回答者という) には氏名と連絡先の記入を依頼した。

【質問内容】下記の(a)〜 (e)からなる。このうち，(a)，(c)， (d)はそれそれ WTP 值との関連を明らかにするために設け た質問項目である。

(a) エネルギー利用に関する意識と認識(原子力と新エ ネルギーに対するイメーシ，現状のエネルギー需給状 況に関する認識，省エネルギーに対する取組みの考え 方)

（b）電源構成の变更を仮定した場合に割増となる電気代 に対するWTP 值(第 2 表参照)

(c) エネルギー利用活動への参加意識(エネルギー政策

第 1 表 アンケート調査における地域と地域別の回収率

\begin{tabular}{|c|c|c|c|c|}
\hline \multicolumn{2}{|r|}{ 地 域 } & 発送数 & 回収数 & 回収率 \\
\hline \multirow{3}{*}{$\begin{array}{l}\text { 立 } \\
\text { 地 } \\
\text { 地 } \\
\text { 域 }\end{array}$} & $\begin{array}{c}\text { 福 島 県 } \\
\text { (大熊町、富岡町、双葉町、楢葉町) }\end{array}$ & 335 & 94 & $29 \%$ \\
\hline & $\begin{array}{c}\text { 新 潟 県 } \\
\text { (柏崎市、刈羽村) }\end{array}$ & 335 & 88 & $27 \%$ \\
\hline & $\begin{array}{c}\text { 福 井 県 } \\
\text { （敦賀市、美浜町、大飯町、高浜町） }\end{array}$ & 335 & 98 & $30 \%$ \\
\hline \multirow{2}{*}{$\begin{array}{l}\text { 都 } \\
\text { 市 } \\
\text { 地 } \\
\text { 域 }\end{array}$} & $\begin{array}{l}\text { 東 京 都 } \\
\text { (2 3区) }\end{array}$ & 500 & 117 & $24 \%$ \\
\hline & $\begin{array}{l}\text { 大阪市 } \\
(24 \text { 区 }\end{array}$ & 500 & 120 & $24 \%$ \\
\hline \multicolumn{2}{|r|}{ 合 計 } & 2005 & 517 & $27 \%$ \\
\hline
\end{tabular}

第 2 表 アンケート調査に設けた CVM 関連分の質問項目

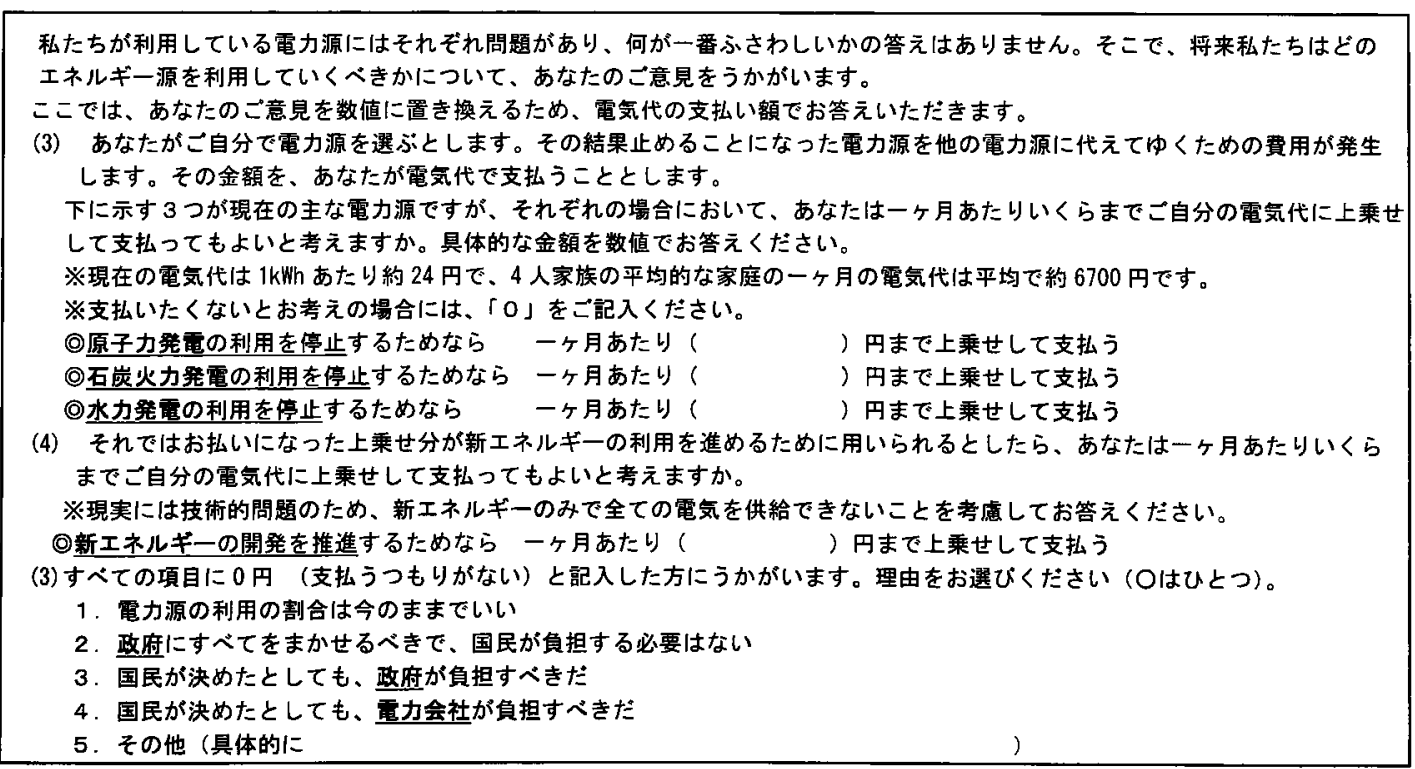

e) 具体的な金額を複数通り提示して，その金額を支払うか否か金額の 2 肢択一のプロセスを 2 回繰り返し尋ねる方法である。すなわち， 最初にある金額を提示してその額を支払うかどうかを尋ね，得られた回答值の集合から集団全体としてのWTP 值の統計値(平均値ある いは中央値)を推定し，支払うと答えた人に対してはさらに金額を增して，支払わないと答えた人に対しては金額を減らして，それそれ 再度支払うかとうかかの意志を尋ねる方法であり，これら２段階のプロセスを通して支払額が決定される。 
に対する意見反映の方法，省エネルギー行動に対する 意欲の持ち方)

(d) 暮らしにおける主観的な要素(生活に対する満足 感, 物質的あるいは精神的な価値観, 日常の購買活動 における用途別支払い感覚）

（e）その他（回答者個人の属性，エネルギ一問題全般お よび本調查の実施に対する自由意見)

【回収結果】地域ごとの発送数と回収率を第 1 表に示

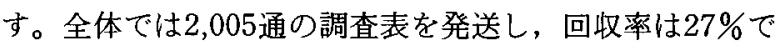
あったき。回収率については, 都市地域は立地地域に比べ て相対的に低く，また立地地域内扔よび都市地域内ではそ れぞれ小さい偏りになっている。なお，全回答者517名の うち，記名回答者は186名で，その占める割合は36\%であ った。

(2) 訪問調查

【調査対象】訪問調查への協力を承諾したアンケート調 查の回答者およびアンケート結果の入手を希望した回答者 の合計175名のうちg)，直接対面が可能であった対象者39 名に面接による調査を実施した。また，日程，面接場所な どの関係で面会が困難であった対象者136名に対しては, 郵送による調査を依頼し，そのうち50名から返送があっ

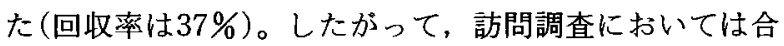
計89名が対象となった。

【実施期間】 2002年10月12日(土） 12月16日（月）

【実施方法】面接による調査は，協力者の自宅あるいは 指定の場所において，直接本人との面会により調査側 2 3 名で聞き取りを行った。対面時間は 1 時間程度とした。 一方，郵送による調查は同様の追加質問の用紙を回答者の 自宅宛に送付し，本人から回答を入手した。

【調査内容】アンケート調査に执いて記入されていた WTP 值について, 変更の有無を確認するとともに, 記入 した WTP 值の決定理由や回答根拠などを尋ねた。

\section{III. 調 査 結 果}

\section{1. アンケート調查の回答結果}

（1）電源選択別 WTP 値の傾向

(a) 電源別 WTP 値の回答結果の分布(ヒストグラム)と 平均值を第 1 図に示す。第 1 図から電源別に分布が 異なること, 新エネルギー以外は共通して支払いを拒 否した抵抗回答の数が特に多いことがわかる。むた, 新エネルギー開発の次に原子力廃止のWTP 值が高 く，今回の CVM 調査からも原子力に対するネガティ ブな意識と新エネルギーに対するポジティブな意識が 対照的に現れていることが示される。

（b）電源別のWTP 值の記入にあたり，何らかの值を記

f) 回収率は住所不明のために返送された未到着分(90通)を除いて 集計した。

g) 記名回答者186名のうち，11名はその後の事情により訪問調查 への協力を辞退した。
入したか否かに注目して回答者を分類すると，第 3 表に示すように，代表的な 6 つのパターン（以下，電 源別 WTP 值回答パターンと呼ぶ)が抽出される。第 3 表を亦ずパターン別で見ると，すべての電源に WTP 值を記入したパターン 1 と，支払いを拒否した 抵抗回答のパターン 2 で全体の過半数を占めている
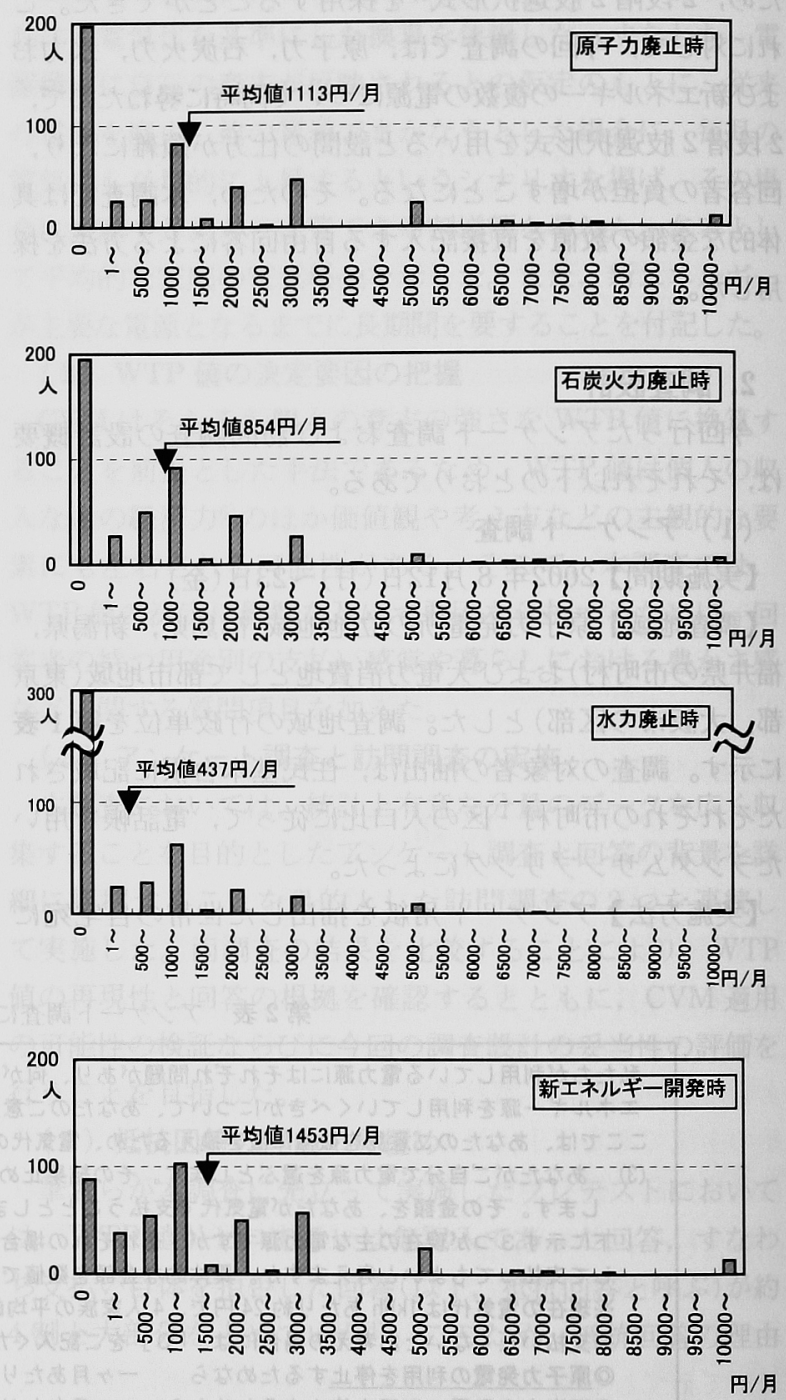

第 1 図電源別 WTP 值の分布

第 3 表 電源別 WTP 值回答パターン

\begin{tabular}{|c|c|c|c|c|c|}
\hline $\begin{array}{c}\text { パターン } \\
\text { 番 号 }\end{array}$ & $\begin{array}{l}\text { 原子力 } \\
\text { 廃止時 }\end{array}$ & $\begin{array}{c}\text { 石炭火力 } \\
\text { 廃止時 }\end{array}$ & $\begin{array}{l}\text { 水 カ } \\
\text { 廃止時 }\end{array}$ & $\begin{array}{c}\text { 新I祅ギ - } \\
\text { 開発時 }\end{array}$ & $\begin{array}{c}\text { 割 合 } \\
(\text { (\%) }\end{array}$ \\
\hline パターン 1 & $*$ & $*$ & $*$ & $*$ & 27.1 \\
\hline パターン 2 & - & - & - & - & 25.7 \\
\hline パターン 3 & * & * & - & * & 15.6 \\
\hline パターン 4 & - & - & - & * & 9.9 \\
\hline パターン 5 & * & - & - & * & 7.8 \\
\hline パターン 6 & - & * & - & * & 7.6 \\
\hline そ の 他 & & & & & 6.2 \\
\hline
\end{tabular}

【備考】*は何らかの玣P 值の記入があったこと、一はぜロあるいは 無記入であったことを示す。 
ことがわかる。一方，電源別では，特に新エネルギー に対する記入が多く，东力に対する記入が少ないなど 電源ごとに意識差のあることが認められる。

(c) パターン2に見られる抵抗回答の理由について は，「電源の割合は現在のままでよいから」が約半数 を占め，次いで「決めるのは国民でも負担は政府や電 力会社がすべきたから」の順になっている。このほか の理由および回答の背景については, 訪問調查の結果 として後述することにする(III-2(2)-(c)項参照)。

(d) 記名回答者と無記名回答者について, 両者のWTP 値を比較した結果を第 4 表に示すん。第 4 表から，水 力以外ではすべて無記名回答者が低いWTP 值を示し ており，原子力および新エネルギーにおいては有意差 が認められた。これから，調查結果に関心のある人々 は，概してWTP 值を高く回答する傾向が見られる。

（2）支払い感覚とWTP 値との関係

電源別 WTP 值に対し影響を及ぼす要因として，まず価 格に対する個人的な感じ力や用途別の支払い感覚の違いに ついて調べたi)。そのため，ここでは，普段の生活におい て3,000円を代表的な 3 つの用途(書籍, 昼食, 難民救済) に支厸う場面を想定し，その際の「むったいなさ」の感じ 方を 4 段階で尋称た に，回答者をもったいないと「思う」グループと「思わない」 グループの 2 つに分けた集計を第 5 表に示す。結果とし て，すべてに有意な差は認められなかったが，もったいな いと「思わない」グループは「思う」グループに比べておお むねWTP 值が高い傾向がある。また，用途別ではそれぞ

第 4 表 記名回答者と無記名回答者の電源別 WTP 值(円/月)

\begin{tabular}{|c|c|c|c|c|}
\hline 回答者 & $\begin{array}{l}\text { 原子力 } \\
\text { 廃止時 }\end{array}$ & $\begin{array}{c}\text { 石炭火力 } \\
\text { 廃止時 }\end{array}$ & $\begin{array}{l}\text { 水 カ } \\
\text { 糜止時 }\end{array}$ & $\begin{array}{c}\text { 新工视快- }- \\
\text { 開発眭 }\end{array}$ \\
\hline 記 名 (286 人) & 1. 589 & 1,105 & 459 & 2,109 \\
\hline 無記名 (166人) & 1,329 & 986 & 551 & 1,722 \\
\hline
\end{tabular}

第 5 表 用途別の支払い感覚加ら見大電源別WTP 值(円/月)

\begin{tabular}{|c|c|c|c|c|c|}
\hline 用速 & $\begin{array}{l}\text { 「もったいない」と } \\
\text { 思う/思わないな゙ルーブ }\end{array}$ & $\begin{array}{l}\text { 原子力 } \\
\text { 糜止時 }\end{array}$ & $\begin{array}{l}\text { 石炭火力 } \\
\text { 穈止時 }\end{array}$ & $\begin{array}{l}\text { 水力 } \\
\text { 廃止時 }\end{array}$ & $\begin{array}{l}\text { 新工祃ギ- } \\
\text { 開発時 }\end{array}$ \\
\hline \multirow[b]{2}{*}{ 笛籍 } & 思 う (178人) & 1,123 & 834 & 546 & 1.384 \\
\hline & 思わない( & & & 357 & .534 \\
\hline \multirow{2}{*}{ 荲食 } & 思 う(243 & 1.038 & 904 & 472 & 1,382 \\
\hline & 思わない (18 & 1.250 & 810 & 406 & 1,575 \\
\hline \multirow{2}{*}{ 蜼民 } & & 1,048 & 699 & 42 & 1,280 \\
\hline & 思わな & 1,184 & 964 & 455 & 1.576 \\
\hline
\end{tabular}

【供考】「もったいないはは用途ごとに 3000 円を支払うとした場合の感党

h)これ以降の分析においては，10,000円以上のWTP 值は外れ値 として扱い，除いて処理した。

i) 個人による経済力や生活環境の違いなどから，回答者の洒格に 対する感覚には差異がある。また，たとえ同じ金額であって も，その時の状況や使い道に応じて支払いに対して異なった受 止め方をするという現象があり，これは，いわゆる心理的財布 効果として知られている。

j）それぞれの支払い場面において「むったいない」と(1)感しる， (2)やや感じる, (3)あまり感じない，(4)感じない，を尋ねた。
れグループ間の WTP 値の開きに大きな差が認められない ことがわかた。

\section{2. 訪問調查の回答結果}

\section{(1) WTP 值の再現性}

アンケート調査において，記入されたWTP 值を訪問調 査で確認することにより，WTP 值の回答の再現性を検証 した。その結果, 訪問調查の回答者89名のうち約 1 割に あたる 9 名が一部の数値を訂正した。訂正の理由には， 「(アンケート調査と訪問調査の間に発生した)原子力発電 所のデータ改ざん報道によって原子力以外の電源を開発す る必要性を感じた」あるいは逆に「(これを機にして)原子 力の必要性を改めて再認識した」とする回答が 4 件あっ た。また，質問の設定条件と異なった解釈に基ついて回答 していたことによる訂正が 4 件含まれていた。

\section{（2）WTP 值回答の根樾}

訪問調査において尋ねたWTP 值の回答の根拠につい て，電源別 WTP 值回答パターンごとに集約した結果を第 6 表に示す。訪問調査からは以下のような事項が明らかに された。

(a) WTP 值を決めた主な根拠や背景については, 「個 人で負担できる金額の範囲で記入した」とするほか，

「本来は全額を国が負担すべきなので，個人としては 実際に支払うことができる金額よりも小額に留めた」 とするものがあった。景気が悪く電気代自体も 安くないため個人負担をしたくてもできない」，「本 来, 電気は公共性の強いものであり, 個人負担はろさ わしくない」とする理由むあった。

(b) 電源への認識 (知識) から見たWTP 値の記入の仕方 については，「化石燃料が地球温暖化に与える影響,

第 6 表 電源別 WTP 值回答パターンこととの主な回答の根拠

\begin{tabular}{|c|c|}
\hline パターン & 回 答 の 根 拠 \\
\hline \multirow{3}{*}{1} & 各電源の問題意識に応じ金額を記入した(12) \\
\hline & 相応の負担は必要である(3) \\
\hline & 節電のためには値上げが有効と考える(1) \\
\hline \multirow{5}{*}{2} & 価格上昇分は政府や電力会社が負担すべきだ (5) \\
\hline & 必要性は認めるが個人負担は無理である(3) \\
\hline & 省エネルギーで解決が可能と思う(2) \\
\hline & 国や企業に不信感がある(1) \\
\hline & 現状とおりでよい(1) \\
\hline \multirow{2}{*}{3} & 水カには問題ないがその他は問題がある(13) \\
\hline & 廃止のために割增料金を支払う必要ない(2) \\
\hline \multirow{7}{*}{4} & 新エネルギー開発に貢献したい(3) \\
\hline & 電源構成は今のまま、変更の際は国が負担すべきだ（3） \\
\hline & 新エネルギーへの投資はやむをえない(2) \\
\hline & 新エネルギ一開発に貢献したい(3) \\
\hline & 電源構成は今のまま、変更の際は国が負担すべきた (3) \\
\hline & 新エネルギーへの投資はやむをえない(2) \\
\hline & 新エネルギーに投資したい(1) \\
\hline \multirow{2}{*}{5} & 原子カは問題だが新エネルギーは開発してほしい(4) \\
\hline & 同上十石炭火力と水力は自然に消滅する(1) \\
\hline \multirow{3}{*}{6} & 原子カと水力は必要なので現状のままとすべきだ(4) \\
\hline & 原子カと水カに問題を感じるがやむをえない(2) \\
\hline & 原子カは必要、水力の廂止のためには払う必要ない(1) \\
\hline
\end{tabular}


自然エネルギー利用実現の困難さ，原子力利用の安全 面でのリスクなど，個々の電源のメリットとデメリッ トに基ついた」とする回答があった。その一方で，具 体的な点には触れずに「新エネルギーに対するクリー ンな感じ，原子力に対する恐ろしさなど個々の電源に 対するイメージに基づいた」とする回答も寄せられて いた。

(c) すべての電源について抵抗回答(パターン2)を示し た理由として，今回の訪問調査からアンケート調査で 設定した選択項目に含まれないものがいくつか取得さ れた。例えば，「個人的には支払いたいが，これ以上 の経済的な負担は無理である」，「政府や電力会社に信 頼が持てず，不適切に使用される恐れがある」，「電力 会社や国の努力が足りないのに一般の人が支払うのは おかしい」、「支払いを課さなくても競争原理を働かせ れば電気代は下がる」「参考データがないので判断が できない」どの理由が奇せられた。

(d) 特定の電源のWTP值をぜロと回答した理由(パ ターン3〜6)についても「(その電源には)問題がある とは思わない」，「(その電源は)必要なので廃止しては ならない」「もともと望ましくない電源に対して負担 をするのはいやだ」「一たん利用を始めたものを廃止 するためにあえて費用をかけるべきでない」など多様 な理由が挙げられた。

\section{IV. 考察と課題}

\section{WTP 值の決定要因の分析}

本章では最初に今回のアンケート調査と訪問調査に基づ
いて，個人的な意識とWTP 值との関係を把握するための 分析を行う。以下に, 第 7 表に挙げた 4 つの要因ごとに 回答者を意見別グループに分け，それぞれのグループ間の WTP値の相違を比較した結果と考察を示す。

(1) 電源に対するイメージとの関係

電源に対する人々の抱くイメージと電源ごとのWTP值 を比較したk)。この結果, 以下に関して有意差が確認され た。すなわち，原子力に対して相対的にポジティブなイ メージを持つ「原子力に肯定的」グループはネガティブな イメージを持つ「原子力に否定的」グループに比べて, 原 子力廃止の WTP 值が低いと同時に, 新エネルギー開発の WTP 值も低い傾向がある。その一方, 新エネルギーに対 して相対的にポジティブなイメージを持つ「新エネルギー に肯定的」グルーブは，ネガティブなイメーシを持つ「新 エネルギーに否定的」グループに比べて，原子力廃止の WTP 值が高いと同時に新エネルギー推進の WTP 值も高 い傾向がある。このように，個人の持つ電源へのイメーシ はWTP 值の決定の際に明らかな影響を及ほすことが確認 された。

（2）エネルギー利用に関する現状認識との関係

エネルギー利用に対する人々の認識 (知識)の程度を捉え るために，わが国の現状の電源割合について尋ねる設問を 設けた。この設問に対して，原子力と新エネルギ一の割合 を「知っている」と回答したグループは，「知らない」と回 答したグループに比べ, 水力を除くすべての電源に対し高 いWTP 值を回答することが認められ，とりわけ，新エネ ルギーの場合は有意に高いことが分かった。このように， 認識(知識)を持つ回答者ほどWTP 值を高く記入する傾向

第 7 表 個人的意識の要因ごとの電源別 WTP 値の比較(円/月)

\begin{tabular}{|c|c|c|c|c|c|c|c|c|c|}
\hline \multicolumn{3}{|c|}{ 要 } & \multicolumn{2}{|c|}{ 意見別グループ } & \multirow{2}{*}{$\begin{array}{l}\text { 原子力 } \\
\text { 廃止時 } \\
{ }^{* * *} 1,657\end{array}$} & \multirow{2}{*}{$\begin{array}{r}\begin{array}{c}\text { 石宸火力 } \\
\text { 廃止時 }\end{array} \\
942\end{array}$} & \multirow{2}{*}{ 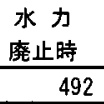 } & \multirow{2}{*}{ 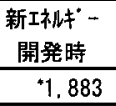 } & \multirow{3}{*}{ 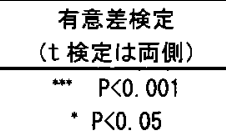 } \\
\hline \multirow{4}{*}{1} & \multirow{2}{*}{\multicolumn{2}{|c|}{ 原子カに }} & 否 定 的 & (108人) & & & & & \\
\hline & & & 肯 定 的 & (96人) & ${ }^{* * *} 491$ & 774 & 387 & $\bullet, 303$ & \\
\hline & \multirow{2}{*}{\multicolumn{2}{|c|}{ 新エ祃ギーに }} & 否 定 的 & (120人) & $* 722$ & 661 & 380 & ${ }^{*} 991$ & \multirow{2}{*}{$* P<0.005$} \\
\hline & & & 肯 定 的 & (84人) & $* 1,346$ & 984 & 391 & $* 1,739$ & \\
\hline \multirow{4}{*}{2} & \multirow{2}{*}{\multicolumn{2}{|c|}{$\begin{array}{c}\text { 原子カの } \\
\text { 割合の認識 }\end{array}$}} & 知っている & (348人) & 1,154 & "910 & 471 & ${ }^{*} 1,536$ & \multirow{2}{*}{ * $P<0.05$} \\
\hline & & & 知らない & (88人) & 902 & *648 & 313 & $* 1,174$ & \\
\hline & \multirow{2}{*}{\multicolumn{2}{|c|}{$\begin{array}{l}\text { 新エ祝ギーの } \\
\text { 割合の㑇識 }\end{array}$}} & 知っている & (188人) & 1,177 & 951 & 427 & $* 1,644$ & \multirow{2}{*}{${ }^{*} P<0.05$} \\
\hline & & & 知らない & (246人) & 1,056 & 793 & 452 & $* 1,316$ & \\
\hline \multirow{5}{*}{3} & \multirow{2}{*}{\multicolumn{2}{|c|}{$\begin{array}{l}\text { 省エ祙ギーへの } \\
\text { 取組み意欲 }\end{array}$}} & 生活レベを下げてでも & $(52 \lambda)$ & $* * 1,860$ & $\because \cdots 1,449$ & ${ }^{* * *} 726$ & ${ }^{* *+2}, 314$ & \multirow{2}{*}{ *nos $P<0.001$} \\
\hline & & & 生活いべれを維持範国で & (355人) & ${ }^{*+9}+977$ & 766 & $* * 387$ & $* * 1,331$ & \\
\hline & \multirow{3}{*}{\multicolumn{2}{|c|}{$\begin{array}{l}\text { I枚 一政策への } \\
\text { 意見反映の方法 }\end{array}$}} & 直接投票を通して & (308人) & ${ }^{* * *} 1,264$ & 898 & 491 & 1,560 & \multirow{3}{*}{$\begin{array}{c}F(2,393)=7.02 \\
P<0.001\end{array}$} \\
\hline & & & 議員に委ねる & (20人) & ${ }^{* * *} 171$ & 652 & 195 & 740 & \\
\hline & & & 行政に従う & $(56 \lambda)$ & $* * 732$ & 667 & 324 & 1.271 & \\
\hline \multirow{6}{*}{4} & \multirow{6}{*}{$\begin{array}{l}\text { 価 } \\
\text { 值 } \\
\text { 観 }\end{array}$} & \multirow{2}{*}{ 豊かさ感 } & モ/の豊かさ志向 & (103人) & "954 & 706 & 453 & 1,449 & \multirow{2}{*}{${ }^{*} P<0.05$} \\
\hline & & & 心の豊かさ志向 & (99人) & $\cdot 1,413$ & $* 1,121$ & 525 & 1,791 & \\
\hline & & \multirow{2}{*}{$\begin{array}{l}\text { 将来の } \\
\text { 㑲え感 }\end{array}$} & 阠型志向 & (102人) & 1,313 & $* 1,067$ & 529 & $* 1,743$ & \multirow{2}{*}{${ }^{*} P<0.05$} \\
\hline & & & 扫ギリス型志向 & (99人) & 911 & $" 660$ & 405 & ${ }^{*} 1,254$ & \\
\hline & & \multirow{2}{*}{$\begin{array}{c}\text { 生活へ } \\
\text { の満足度 }\end{array}$} & 満足している & (294人) & 1,160 & 942 & 451 & 1,526 & \multirow{2}{*}{ 有意差なし } \\
\hline & & & 不満である & (138人) & 1,062 & 691 & 415 & 1.363 & \\
\hline
\end{tabular}

k1 電源に対するイメージの回答結果から，回答者の原子力および新エネルギーに対するポジティブからネガティブへの得点を計算し，そ れぞれの得点が上位四分位点以上のグループを肯定的グループ，下位四分位点以下のグルーブを否定的グループとして扱った。 
があることから，新エネルギーについては実現が困難であ ることを理解した上での回答であることが推測される。

\section{（3）問題解決に対する皘極性との関係}

人々の行動の積極性とWTP值との関係を調べるため に，まず省エネルギーへの取組みと生活レベルのバランス についての考え方を尋ねた。この結果,「生活レベルを下 げてでも」省エネルギーに取組むとした回答者グループ は，「生活レベルを維持する範囲で」取組むとしたグルー プに比べて，すべての電源に対し高いWTP 值を示すこと が有意に認められた。次に，エネルギー政策への意見反映 の方法についての設問に対しては，「直接投票を通して」 参加意識を反映させたいとするグループは，「議員に委ね たい」などするグループよりもWTP 值を高く回答してい る。これらの分析から，問題解決に対する意欲や態度が強 いほど高いWTP 値を示す傾向が確認された。

\section{(4) 生活上の価値観との関係}

人々の生活面での価値観とWTP 值との関係を調べるた めに，暮らしに打引る物質的・精神的な豊かさ感，将来の 備えに対する考え方，日常の生活に対する満足度を尋ねる 質問を設けた。設問ごとにそれぞれ回答者を2グルーフ に分類し，グループ間の WTP 值を比較した1)。その結 果，まず精神的に豊かであることを重視する「心の豊かさ 志向グループ」は，物質的に満たされることを重視する 「モノの豊かさ志向グループ」に比べてWTP 值を高く回 答しており，原子力と石炭の場合については有意差が認め られた。また，将来の備えを重視する「アリ型志向グルー プ」は，現状の生活を重視する「キリギリス型志向グルー プ」よりWTP 值を高く回答しており，石炭と新エネル ギーの場合については有意であることが確かめられた。さ らに, 生活への満足度とWTP 值との関係については, 現 状の生活水準(衣食住など)に「満足している」としたグルー プは「不満である」としたグループに比べて，有意な差で はないものの全般的に高いWTP 值である傾向が認められ た。このように, 回答者の価值観の持ち方によってWTP 值も異なることが示された。

\section{CVM の適用性と今後の課題}

本章では，筆者らの行った今回の調査の結果と分析に基 つき，人々の電源選好意識の把握に対する CVM 適用の可 能性と今後の問題点について, 以下の $2 つ の$ 観点から考 察を加える。

（1）関与意識の定量化の可能性

これまでに述べた調査結果とその分析から，CVMの適 用性についてはいくつかの課題はあるもののおおむね認め られるむのと考える。すなわち，個人的な電源選択という

1) 価値観に関する 3 つの設問の回答結果を因子分析することによ $\eta$ ，回答者のそれぞれの志向得点を求め，この得点が上位四分 位点以上の回答者と下位四分位点以下の回答者をそれそれ代表 するグループとして扱った。
架空の条件を設定することにより，人々の関与意識を WTP 值を用いて定量化することの調查設計の有効性に関 して基本的な方向は妥当であったと思われる。また，訪問 調査によってWTP 值の再現性と回答の背景を確認するプ ロセスの追加は，新たな調查上の視点を発見するためにも 有益であったと考える。たたし，以下の点については今後 にさらなる見直しの検討を必要とする。

(a) 調査設計については，条件の設定に不合理な点や説 明不足な点があり，一部の回答者に設定条件に対する 䛊解が見受けられた。例えば，新エネルギーは開発の ための支払い額を問うているが，その他の在来型電源 は廃止のための支払い額を尋ねているため, 回答者が 各自の支払い行動を共通した基準で評価し難い点があ った。このような条件設定の不備は CVM の手法とし て本質的に避けられないものであるが，プレテストの 充実などによりこうしたバイアスを極小化するための 検討は引き続き進めるべきである。

(b) 電源選択により自らの電気代が増加するという論理 や, 電気代の值上がりが生活全般に影響を及ほす仕組 みに対する人々の関心は概して低いことが明らかにな った。とりわけ, 新エネルギーの開発に伴うコストに ついての認識が一般に薄いことが訪問調査の結果から 確認された。このような経済的な認識の解明のために 今後の CVM の手法の見直しが望むれる。

(c) 原子力の廃止に対するWTP 值については，筆者ら が先に実施した段階 2 肢選択法で尋ねたプレテスト に扔ける回答值よりも, 今回の值は低い結果となって いるm。 この回答值の差異を生む原因が 2 段階 2 肢選 択法と自由回答法との違いによるものか, あるいは調 查の時期や社会情勢の変化に由来するものであったか については，今回明らかにできなかった。この点に関 しても今後の検討が必要である。

\section{（2）意識の背景把握の可能性}

電源選択に際して人々の意識の背景にある要因とWTP 値との関係を分析することについては，回答値の分散が大 きいために有意差についての確証性は低いものの, 用途や 価格などによる個人の支払い意識の違いが WTP 值に影響 していることが確認された。従来の CVM 調查でもこのよ うな要因との関保は分析されているが，今回は訪問調査を 追加害施することにより回答者の持つ電源に対する見解や 評価を直接確認することができた。これにより，国や自治 体や電力会社など供給側に対する信頼感, 個人的に関与が 可能な分野や参加の意欲, 電力供給システムの公共性に対 する考え方なども強く関係していることを改めて実証した 点は有益と考える。しかしながら，以下の点が今後の検討 課題として残されている。

m) 2 段階 2 肢選択法を用いたブレテストにおける回答値は，平均 值で約4,000円となっている。 
(a) 新エネルギ一開発に対する支払い感覚や省エネル ギー取組みへの期待や意欲が，現状の生活における满 足感あるいは難民救済のような奉仕意識に関係してい る可能性が推測される。この点については，人々の価 値観とエネルギー利用意識との相関を探る点から興味 深く，今後の補足調查が望まれる。

(b) 原子力の必要性を認識しながらも廃止すべしとの回 答がいくつか確認された。また，国民の直接的関与が 必要とする意見が，政府による規制が必要とする意見 に变わるケースも確認された。今後このような一見矛 盾したWTP 値決定の根拠についてさらに精査するこ とが必要であり，それが電源選択についての国と人々 との議論の糸口になると考えられる。

(c) 今回のアンケート調査と訪問調査の間の時期に，偶 然にも事業者による原子力発電所のトラブル陉し事象 が発生した。実際に今回の調査に执いても，一部の立 地地域において回答にその影響が見られた。このよう な社会情勢の变化による人々の意識の变容に関する定 量化についても，別途の課題として今後も留意してい く必要がある。

なお，そのほかに留意すべき点として，金銭的負担を負 うことが現実になった場合に，こうしたWTP 値の回答結 果と現実の支払いとの間のギャップが発生することがあ る。今回の調査結果で示されたWTP 值は毎月の電気代の 数割程度を占めているにもかかわらず，実際には 1 口500 円のグリーン料金制度の普及が滞っている現状を考えて も，仮に将来に割増し料金が義務づけられた場合，その同 意を得ることは難しいものと思われる。

\section{V. 結言}

本研究では，人々の電源選択への関与の観点から, 電気 料金の支払いという個人負担を前提として，CVMにより 人々の電源選好の意識を定量的に把握することを試みた。 また，アンケート調査と訪問調查を実施することで，両者 の回答の再現性を見極め, 回答内容の確認と回答理由の背 景を探った。この結果, 今回の調査の主要な集約として以 下の知見を得た。

（1）CVM を用いた回答結果から，原子力に対するネ力゙ ティブな意識と新エネルギーに対するポジティブな意 識が明確に現れていることが確認された。しかし，一 般にエネルギー事情に対する人々の認識は概して低 く，特に新工ネルギーについては理解が十分でないこ とが推察された。また，回答のWTP 值が同じであっ ても，電源ごとの必要性と実現性を認識したうえでの 回答と理想論の域に留まった回答とが混在しているこ とが認められた。

（2）電源別 WTP 值は，電源の種別に対する選好意識の
みならず，現在のエネルギー事情に関する認識，政策 決定や省エネルギ一活動への積極性，さらには，日常 生活に抢ける支払い意識や暮らしの面での満足感の上 うな個人としての価值観にも左右されることが示され た。これらから，CVMに基づく調査は人々の観念的 な意識の程度の把握のみに留まらず，実際の選択行動 の背景を推定することにも役立つことがわかった。

（3）人々の電源選択に対する CVM の適用の可能性につ いては，いくつかの検討事項は残されているものの， 方向性としてはおおむむね妥当であると判断できる。し かし，今回関連の見られた要因をより詳細に解明する ために，今後の主な課題として，調査設計に関しては 仮定条件の提示方法をより具体的かつわかりやすく改 良すること，また分析方法に関しては，コンジョイン 卜分析の実施ならびに結果の比較を試みることなどが 挙げられる。

現在, 原子力発電の推進者側に対する人々の信頼感の低 下により，わが国の原子力開発計画に遅れが生じている。 加えて，関連した不具合の発生により原子力発電所の運転 停止が余儀なくされ，電力不足の国民生活への直撃も懸念 された。このような状況のなかで, 推進者側には消費者側 の視点に立った見方が期待される一方，人々には貴重な資 源の消費者としての立場を認識した上で，原子力政策に対 し自らの意見を持ち，それを反映させていく主体的な姿勢 が求められる。今回の調査で明らかにされた人々の意識や 採用した分析方法が今後の推進側と消費者側との円滑な対 話に多少なりとも貢献できれば幸いである。

本研究の実施にあたっては，エネルギー政策研究所神田 啓治所長ならびに神田・中込ゼミ(東京ゼミ)の参加諸氏か ら数々の貴重なご示唆・ご助言を頂いた。ここに深く感謝 の意を表したい。

\section{一参考文献一}

1）例えば，総理府広報室，エネルギーに関する世論調査， (1999).

2）鴐田豊明, 栗山浩一，竹内憲司(編), 環境評価ワークショッ プ一評価手法の現状，築地出版，(1999）。

3）朝日基雄, “原子力発電の外部性に関する研究 仮想評価法 (CVM)を用いた原子力発電への不安感の定量評価,”京都大 学大学院エネルギー科学研究科平成 12 年度エネルギー社会・ 環境科学専攻修士論文, (2001).

4）野村 昇, 赤井 誠, “自然エネルギ一電力への支払い意志額に ついての CVM 調查，”エネルギー資源・資源，23[4]53〜58 (2002)

5）高橋玲子，宮沢龍雄，中込良廣，神田啓治，“仮想評価法に上 る人々の原子力に対する態度の評価(I)，”原子力学会「2002 春の年会」要旨集, A8, p. 546 (2002).

6）栗山浩一，公共事業上環境の価値，築地書館，(1997）。 